\title{
KARAKTERISASI BAHAN BAKAR PADA MOTOR DIESEL
}

\author{
(FUEL CHARACTERIZATION ON DIESEL ENGINE)
}

\author{
Wardan Suyanto, Budi Tri Siswanto, Muhkamad Wakid \\ Fakultas Teknik Universitas Negeri Yogyakarta \\ Jalan Colombo No.1 Yogyakarta \\ e-mail: wardan.s@lycos.com, wardansuyanto@uny.ac.id
}

\begin{abstract}
Abstrak
Penelitian ini bertujuan untuk mengetahui karakteristik: (1) konsumsi bahan bakar motor diesel 4 langkah ditinjau dari perubahan timing injeksi pada penggunaan biosolar dan Pertamina Dex, (2) opasitas gas buang pada motor diesel yang dihasilkan ditinjau dari perubahan timing injeksi pada penggunaan biosolar dan pertamina dex. Penelitian dilakukan dengan pendekatan eksperimen pada motor diesel 4 langkah 1 silinder direct injection berdaya maksimum 4200 watt. Pengontrolan dilakukan pada putaran dan beban mesin melalui beban kelistrikan dari generator. Pengumpulan data dilakukan dengan observasi. Data dianalisis melalui perhitungan rata-rata dan disajikan dalam bentuk tabel dan grafik. Hasil penelitian menunjukkan bahwa: (1) konsumsi bahan bakar paling efisien saat timing injeksi $30^{\circ}$ sebelum TMA (maju) dengan biosolar, sedangkan ketika dimundurkan cenderung semakin boros, dan (2) opasitas gas buang paling rendah berada pada timing injeksi $30^{\circ}$ sebelum TMA (maju) dengan Pertamina Dex dan semakin tinggi ketika dimundurkan.
\end{abstract}

Kata kunci: konsumsi bahan bakar, opasitas gas buang, Pertamina Dex, biosolar, timing injeksi

\begin{abstract}
This study aims to know the characteristics of: (1) fuel consumption on four stroke diesel engine in terms of the fuel injection timing variation in application of biosolar and Pertamina Dex, (2) emission opacity on four stroke diesel engine in terms of the fuel injection timing variation in application of biosolar and Pertamina Dex. This study used experimental approaches on four strokes single cylinder direct injection diesel engine with 4200 watts on maximum power. The engine speed and load were controlled by electricity load of electric AC generator. Observation was used to collect the data. The data was analyzed with mean calculation and showed with tables and graphics.The result of this study showed that: (1) the most efficient of fuel consumption is reached when injection timing in $30^{\circ}$ before TDC (advanced) with biosolar, while in retreated condition is more uneconomical, (2) the least emission opacity is reached when injection timing in $30^{\circ}$ before TDC (advanced) with Pertamina Dex and worse in retreated condition.
\end{abstract}

Keywords: fuel consumption, emission opacity, Pertamina Dex, biosolar, injection timing

\section{PENDAHULUAN}

Masalah pencemaran udara merupakan hal yang sangat esensial bagi masyarakat terutama menyangkut kesehatan. Kondisi yang ada, ternyata emisi dari kendaraan bermotor menyumbang sekitar $70 \%$ terhadap pencemaran udara di daerah Republik Indonesia (Anonim, 2011). Oleh sebab itu, 
kebijakan di bidang transportasi semakin ketat berkaitan dengan polusi gas buang kendaraan.

Berdasarkan keputusan menteri Lingkungan Hidup Nomor 141/2003 tentang baku mutu emisi kendaraan, setiap kendaraan bermotor harus memenuhi standar EURO 2 baik untuk kendaraan bermotor bensin maupun diesel. Konsekuensi berlakunya standar EURO 2 ini adalah setiap kendaraan harus memiliki emisi yang rendah sesuai karakteristik mesin penggeraknya. Untuk mencapainya, kondisi mesin harus berada dalam kondisibaik serta didukung penggunaan bahan bakar yang baik agar mampu berkerja dengan optimal.

Motor diesel merupakan salah satu sumber pencemaran udara bagi lingkungan baik dari sektor transportasi maupun penggunaan industri karena kepekatan asapnya. Gas buang motor diesel yang pekat dapat mengakibatkan gangguan pandangan maupun gangguan kesehatan. Namun, dengan efisiensi termal cukup tinggi, motor diesel banyak dipakai sebagai sumber penggerak transportasi maupun untuk kegiatan industri.

Opasitas gas buang yang pekat dapat muncul sebagai akibat kerusakan pada mesin maupun kesalahan penyetelan yang kurang tepat, sehingga performansi motor tidak optimal. Namun tidak hanya itu, bahan bakar yang kurang sesuai diduga juga sebagai salah satu penyebab timbulnya hal ini.
Masalah lain pada penggunaan motor bakar termasuk motor diesel sebagai sumber penggerak dalam berbagai aktivitas kerja manusia adalah naiknya harga minyak dunia seiring berkurangnya ketersediaan minyak bumi. Seperti yang diketahui bahwa minyak bumi adalah sumber daya alam yang tidak dapat diperbarui, perlu adanya efisiensi penggunaan bahan bakar motor diesel. Kondisi ini dapat diperoleh dengan kendisi motor yang baik serta penyetelanpenyetelan sistem kerja motor yang sesuai untuk memperoleh performansi motor diesel yang efisien.

Pembakaran yang terjadi pada motor diesel berbeda dengan motor bensin. Motor bensin harus memercikkan bunga api untuk memulai pembakaran, namun motor diesel memulai pembakaran dengan memanfaatkan panas hasil kompresi udara. Oleh karena itu, perbandingan kompresi untuk motor diesel lebih tinggi dari motor bensin yaitu berkisar 12-24 : 1 (Heywood, 1988). Bahkan, hasil tekanan udara pada saat akhir kompresi hingga mencapai 3100 sampai $3800 \mathrm{kN} / \mathrm{m} 2$ (Garrett et al., 2001). Pada kondisi ini, jika temperatur udara di ruang bakar sebelum dikompresi $60{ }^{\circ} \mathrm{C}$, maka temperatur udara ketika telah dikompresi dapat mencapai 675 ${ }^{\circ} \mathrm{C}$. Akibatnya, bahan bakar mampu terbakar dengan temperatur ini, sebab bahan bakar diesel dapat mampu terbakar sendiri pada temperatur $340-350^{\circ} \mathrm{C}$ (Garrett et al., 2001). Setelah udara dikompresi, selanjutnya 
dilakukan penginjeksian bahan bakar di ruang bakar.

Dengan pembakaran yang terjadi karena panas udara, pembakaran pada motor diesel tidak serta-merta terjadi, namun memiliki beberapa tahap (Sukoco dan Zainal Arifin, 2008). Menurut Garrett et al., (2001), tahap pembakaran motor diesel meliputi periode penundaan pembakaran, periode perambatan pembakaran, periode pembakaran langsung, serta periode pembakaran lanjut. Masingmasing periode pembakaran harus sesuai dengan posisi torak. Untuk memperoleh pembakaran yang optimal, periode penundaan pembakaran harus terjadi dengan singkat, sehingga segera terjadi pembakaran pada bahan bakar. Pada putaran yang semakin tinggi, injeksi bahan bakar perlu dimajukan, agar pembakaran dapat terjadi dengan optimal sehingga tenaga mesin dapat optimal serta berefek pada emisi gas buang yang baik (Garrett et al., 2001). Oleh karena itu, injeksi bahan bakar yang dilakukan harus pada waktu yang tepat, sehingga kondisi udara pada silinder sesuai dengan kebutuhan pembakaran bahan bakar.

Selain kondisi motor diesel, komponen masukan yang penting adalah bahan bakar. Di Indonesia, bahan bakar motor diesel yang sering digunakan adalah biosolar dan Pertamina Dex yang memiliki properties yang berbeda. Kedua bahan bakar ini sekilas nampak sama, namun memiliki karakteristik yang berbeda. Salah satunya angka cetane, dimana pertamina dex lebih tinggi daripada biosolar. Namun, konsekuensi harganya juga berbeda. Pada bulan Juli 2014, Pertamina Dex memiliki harga Rp. 143.500,00 per 10 liternya, atau Rp 14.350,00 perliternya, sedangkan biosolar Rp. 5.500,00 perliter dengan subsidi (tempo.co). Pertamina Dex diklaim cocok untuk motor diesel dengan teknologi yang tinggi karena memiliki zat pengotor yang rendah.

Selain zat pengotornya, Pertamina Dex memiliki nilai cetane yang lebih tinggi daripada biosolar disamping berbagai properties bahan bakar lainnya. Nilai cetane biosolar sebesar 48, sedang Pertamina Dex sebesar 51 (Keputusan Direktur Jenderal Minyak dan gas Bumi Nomor 3675 K/24/ DJM/2006). Angka cetane merupakan indikator kualitas suatu bahan bakar bila ditinjau dari kecepatan terbakarnya bahan bakar untuk motor diesel. Semakin tinggi angka cetane pada suatu bahan bakar, maka akan mengurangi waktu tunda pembakaran sehingga bahan bakar tersebut akan dapat terbakar lebih cepat (Garrett et al., 2001). Dengan berbedanya angka cetane, pada timing injeksi yang sama, maka pembakaran yang dihasilkan akan berbeda, sebab periode pembakaran yang terjadi berbeda. Hasilnya, efisiensi bahan bakar yang ada memungkinkan berbeda antara biosolar dan Pertamina Dex pada kondisi timing injeksi yang sama.

Selain konsumsi bahan bakar, faktor lain yang menjadi indikasi kualitas pembakaran 
adalah kondisi emisi gas buang motor diesel. Salah satu karakteristik gas buang motor diesel adalah ditinjau dari kepekatannya. Zainal Arifin dan Sukoco (2009) menyatakan bahwa gas buang motor diesel sebagian besar berupa partikulat, yang membentuk opasitas yang berlebihan. Emisi ini berbentuk partikel debu yang sangat kecil $( \pm 0.01 \mu \mathrm{m})$ yang terbentuk dari senyawa-senyawa karbon dan bahan kimia lain dalam proses pembakaran. Oleh karena itu, sebagai efek pembakaran, opasitas gas buang dapat mengindikasikan pembakaran dalam ruang bakar.

Motor diesel yang digunakan diharapkan dapat menghasilkan tenaga yang besar, hemat bahan bakar, serta menghasilkan opasitas yang rendah. Oleh karena itu, di samping peran teknologi, kondisi penyetelan motor diesel seperti timing injeksi dapat mempengaruhi performa motor. Selain itu, pemakaian bahan bakarnya yang memiliki nilai cetane yang tinggi akan mendukung performa motor diesel untuk bekerja secara optimal.

Penelitian Ainul Rofiq (2011) tentang analisis perbandingan performansi dan emisi gas buang motor diesel dengan menggunakan bahan bakar biosolar dan Pertamina Dex, menunjukkan bahwa bahan bakar bio solar menghasilkan BHP < 0,31 HP dari Pertamina Dex, BSFC yang dihasilkan dari bahan bakar bio solar > 0,143 kg/HP.jam dari Pertamina Dex, dan efisiensi yang dihasilkan dari bahan bakar biosolar < 1,097\% dari Pertamina Dex, data tersebut diukur pada beban 2700 watt dengan putaran $2500 \mathrm{rpm}$. Dengan nilai kepekatan, bahan bakar bio solar $<0,7 \%$ dari Pertamina Dex.

Penelitian yang dilakukan oleh Bambang Supriyatno (2007) tentang analisis perbandingan unjuk kerja motor diesel dengan menggunakan bahan bakar solar dan solar Dex standar. Dalam pengujian ini didapat timing injeksi terbaik adalah 140 BTDC dengan peningkatan daya, torsi, Bmep, Sic, dan efisiensi termal masingmasing sebesar 13,63\%,12\%, 13,16\%, dan $5,73 \%$. Konsentrasi soot dual-fuel engine sangat kecil dibandingkan dengan soot yang dihasilkan mesin diesel konvensional, yaitu terjadi penurunan 94,47-99,27\%, sedangkan perbedaan konsentrasi soot di antara variasi timing injeksi tidak begitu signifikan.

Penelitian mengenai bahan bakar diesel dengan timing injeksi juga dilakukan oleh Hermawan (2004), tentang pengaruh perubahan timing injeksi terhadap unjuk kerja mesin diesel empat langkah berbahan bakar ganda. Hasil pengujian menunjukkan bahwa dengan memajukan timing injeksi akan makin memperbaiki unjuk kerja terhadap dual-fuel timing injeksi standard. Dalam pengujian ini didapat timing injeksi terbaik adalah 14O BTDC dengan peningkatan daya, torsi, Bmep, Sic, dan efisiensi termal masingmasing sebesar 13,63\%,12\%, 13,16\%, dan $5,73 \%$. Konsentrasi soot dual-fuel engine sangat kecil dibandingkan dengan soot yang dihasilkan mesin diesel konvensional, yaitu 
terjadi penurunan 94,47-99,27\%, sedangkan perbedaan konsentrasi soot di antara variasi timing injeksi tidak begitu signifikan.

Pertamina Dex dan biosolar merupakan jenis bahan bakar motor diesel yang disediakan di Indonesia. Dengan nilai cetane yang berbeda, serta berbagai properties yang berbeda, bagaimanakah karakteristik penggunaan biosolar terhadap konsumsi bahan bakar dan opasitas gas buang bila ditinjau dari timing injeksinya? Bagaimanakah karakteristik penggunaan Pertamina Dex terhadap konsumsi bahan bakar dan opasitas gas buang bila ditinjau dari timing injeksinya?

Berdasarkan pertanyaan di atas, maka dilakukan penelitian yang bertujuan untuk: (1) Mengetahui karakteristik konsumsi bahan bakar motor diesel 4 langkah bila ditinjau dari perubahan timing penginjeksian bahan bakar pada penggunaan biosolar dan Pertamina Dex. (2) Mengetahui karakteristik opasitas gas buang motor diesel 4 langkah yang dihasilkan bila ditinjau dari perubahan timing penginjeksian bahan bakar pada penggunaan biosolar dan Pertamina Dex.

\section{METODE PENELITIAN}

Penelitian ini dilakukan dengan pendekatan eksperimen, yaitu melihat dampak penggunaan bahan bakar biosolar dan perubahan timing injeksi terhadap konsumsi bahan bakar dan emisi gas buang pada motor diesel dengan mengontrol beban mesin.
Demikian pula hal ini dilakukan pada bahan bakar Pertamina Dex.

Penelitian dilaksanakan di Laboratorium Jurusan Pendidikan Teknik Otomotif Fakultas Teknik Universitas Negeri Yogyakarta. Penelitian dilaksanakan pada bulan Juni sampai dengan September 2014.

Pengumpulan data pada penelitian ini menggunakan metode observasi. Observasi dilakukan untuk mengetahui variasi pembebanan, timing injeksi, konsumsi bahan bakar, dan opasitas gas buang yang dihasilkan. Tahap pengambilan data penelitian ini sebagai berikut: (1) Memanaskan motor sampai suhu kerja. (2) Pengambilan data pertama dilakukan dengan menggunakan bahan bakar biosolar dengan timing injeksi standar kemudian dilakukan pengukuran sebagai berikut: (a) Pengendalian beban motor dengan beban kelistrikan generator listrik. (b) Pengukuran konsumsi bahan bakar. (c) Pengukuran opasitas gas buang. (d) Pengujian dilaksanakan pada beberapa variasi pembebanan mesin, beban kelistrikan yang diberikan meliputi tanpa beban, beban 5, 10, 15, dan 20 ampere dengan tegangan kerja sekitar 220 volt. (3) Dengan kondisi mesin dan timing injeksi yang sama, bahan bakar diganti dengan Pertamina Dex. (4) Percobaan berikutnya dilakukan dengan menggunakan bahan bakar biosolar dengan merubah timing injeksi maju. Selanjutnya dilakukan pengukuran seperti poin 2. (5) Dengan kondisi mesin dan timing yang sama, bahan 
bakar diganti dengan Pertamina Dex dan dilakukan pengukuran poin 2. (6) Melakukan langkah 4 dan 5 dengan merubahan timing injeksi menjadi mundur dari standar sebesar $5^{\circ}$, sehingga diketahui berbagai kondisi dari beberapa variasi timing dan pembebanan mesin tersebut.

Skema peralatan yang digunakan dapat dilihat pada Gambar 1.

Data dianalisis melalui perhitungan energi listrik yang dibangkitkan motor diesel pada setiap volume bahan bakarnya. Analisis berikutnya menggunakan grafik yang menunjukkan hubungan antara timing injeksi, konsumsi bahan bakar, dan emisi gas buang pada penggunaan biosolar dan Pertamina Dex.

\section{HASIL DAN PEMBAHASAN}

\section{Hasil Penelitian}

Penelitian mengenai biosolar dan Pertamina Dex dilakukan dengan mem- bandingkan efek aplikasi kedua bahan bakar. Perbandingan dilakukan pada motor diesel 4 langkah 1 silinder yang berputar konstan + 3000 rpm dengan melakukan pengontrolan pembebanannya saat temperatur kerja. Pembebanan dilakukan dengan memberi beban kelistrikan melalui generator listrik, sehingga diketahui energi yang dibangkitkan motor pada setiap perlakuan melalui pengukuran tegangan maupun arus pembebanannya. Dalam pengambilan data, dilakukan beberapa variasi timing injeksi timing standar (20 $0^{\circ}$ sebelum TMA), timing maju (30 sebelum TMA) dan timing mundur ( $15^{\circ}$ sebelum TMA). Kemudian diamati besarnya energi yang dibangkitkan (joule/cc) dan opasitas gas buangnya (\%) untuk mengetahui konsumsi bahan bakar dan kondisi emisi gas buang motor diesel.

Data konsumsi bahan bakar dapat diketahui dari seberapa banyak bahan bakar

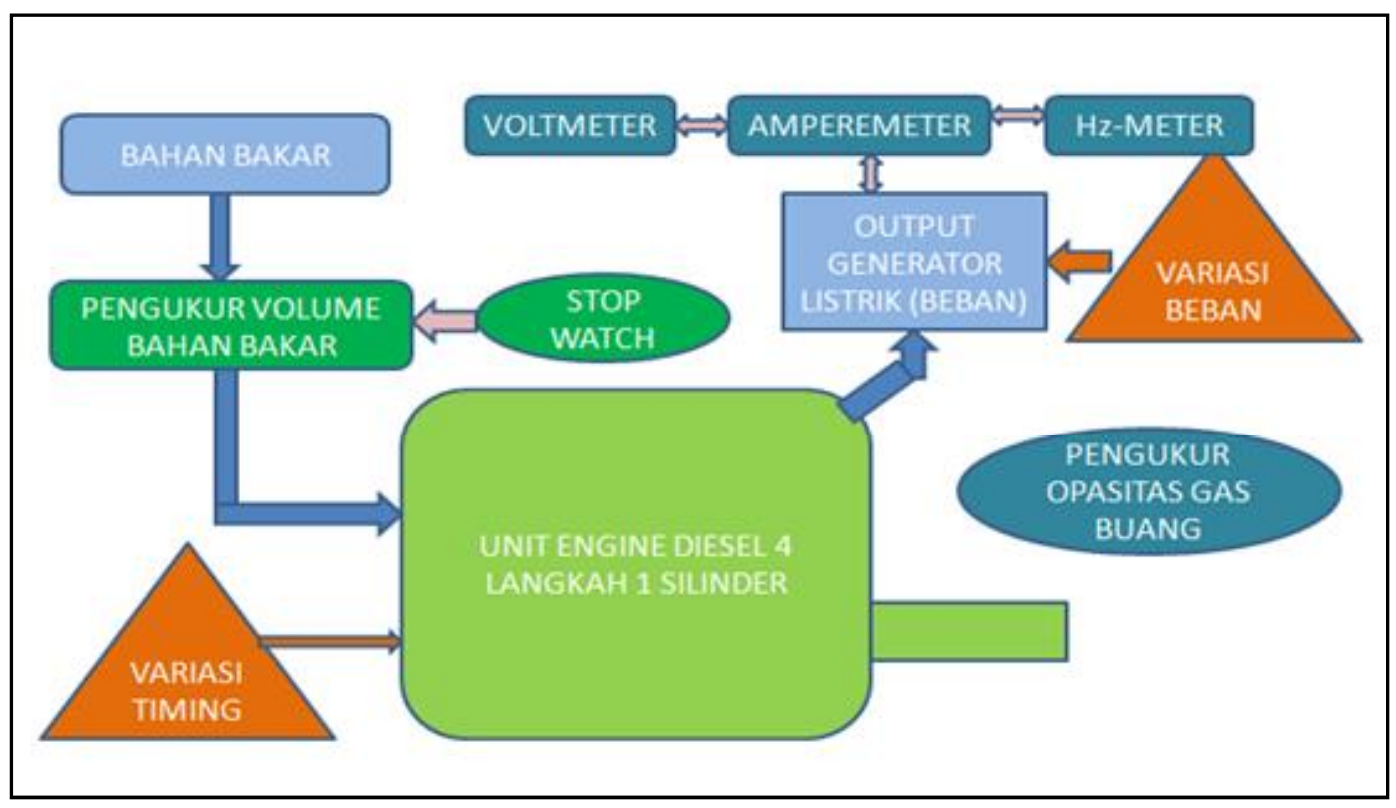

Gambar 1. Skema peralatan pengambilan data 
yang diperlukan untuk membangkitkan sejumlah energi gerak. Namun, karena temperatur bahan bakar antara biosolar dan Pertamina Dex sebagai data ujinya sama, yaitu temperatur ruangan, maka data yang diambil didasarkan pada volume bahan bakarnya. Data konsumsi bahan bakar pada penelitian ini diambil melalui data besarnya energi listrik yang dapat dibangkitkan motor diesel setiap volume bahan bakarnya. Dalam hal ini, satuan energi tiap volume tersebut adalah joule/cc. Data hasil percobaan mengenai besarnya energi yang dibangkitkan pada tiap perubahan timing penginjeksian dan pembebanan mesin untuk kedua bahan bakar baik biosolar maupun Pertamina Dex dapat dilihat pada Tabel 1.

Berdasarkan data yang ditunjukkan pada tabel 1, terdapat perbedaan besar energi yang dibangkitkan pada tiap perubahan pembebanan dan perubahan timing injeksi setiap volume bahan bakarnya. Selain itu, jika diamati untuk penggunaan kedua jenis bahan bakar, efisiensi penggunaan bahan bakar terjadi pada saat timing dimajukan sebesar $10^{\circ}$ dari timing standar ( $30^{\circ}$ sebelum TMA). Kemudian disusul dengan timing standar dan timing mundur. Selain terlihat perbedaan efisiensi penggunaan bahan bakar dari timing injeksinya, penggunaan bahan bakar yang berbeda juga menujukkan konsumsi yang berbeda. Energi yang dibangkitkan setiap volume bahan bakar pada timing standar dan timing yang mundur ternyata melalui penggunaan Pertamina Dex lebih unggul. Namun, pada timing maju, konsumsi bahan bakarnya terlihat penggunaan biosolar lebih unggul daripada Pertamina Dex namun tidak berbeda jauh.

Pengamatan juga dilakukan pada opasitas gas buang yang dihasilkan motor diesel pada beberapa kondisi, baik pada timing injeksi yang berbeda, pembebanan motor yang berbeda, maupun penggunaan bahan bakar biosolar maupun Pertamina Dex. Opasitas gas buang ditentukan dalam persen (\%). Semakin rendah nilai opasitas gas buangnya, maka performa mesin lebih baik sebab polusi yang dihasilkan relatif lebih sedikit. Data hasil pengukuran terhadap opasitas gas buang yang dihasilkan dapat dilihat pada Tabel 2.

Berdasarkan data pada Tabel 2, ditunjukkan bahwa opasitas gas buang yang

Tabel 1. Energi (dalam joule/cc) pada Berbagai Timing dan Pembebanan Motor Diesel

\begin{tabular}{ccccccc}
\hline \multirow{2}{*}{ Beban (A) } & \multicolumn{2}{c}{ Timing Maju } & \multicolumn{2}{c}{ Timing Standar } & \multicolumn{2}{c}{ Timing Mundur } \\
\cline { 2 - 7 } & Biosolar & P.Dex & Biosolar & P. Dex & Biosolar & P. Dex \\
\hline 5 & 5273.2 & 5203.4 & 4947.4 & 5209.0 & 4621.8 & 4920.0 \\
10 & 8030.1 & 7832.9 & 7046.1 & 7792.4 & 7073.4 & 7279.7 \\
15 & 9048.3 & 8969.0 & 7954.8 & 8937.6 & 7473.3 & 7960.7 \\
20 & 9325.5 & 9250.6 & 7848.8 & 9137.2 & 6316.5 & 7884.0 \\
\hline Mean & 7919.3 & 7814.0 & 6949.3 & 7769.0 & 6371.2 & 7011.1 \\
\hline
\end{tabular}


Jurnal Penelitian Saintek, Vol. 20, Nomor 1, April 2015

Tabel 2. Opasitas Gas Buang (dalam \%) Berbagai Timing Injeksi dan Pembebanan Mesin

\begin{tabular}{ccccccc}
\hline \multirow{2}{*}{ Beban (A) } & \multicolumn{2}{c}{ Timing Maju } & \multicolumn{2}{c}{ Timing Standar } & \multicolumn{2}{c}{ Timing Mundur } \\
\cline { 2 - 7 } & Biosolar & P. Dex & Biosolar & P. Dex & Biosolar & P. Dex \\
\hline 0 & 1.60 & 0.04 & 5.27 & 2.90 & 5.77 & 5.03 \\
5 & 2.80 & 0.08 & 4.50 & 4.80 & 6.73 & 2.30 \\
10 & 3.70 & 0.09 & 5.10 & 4.87 & 7.00 & 5.53 \\
15 & 6.07 & 0.18 & 7.93 & 6.40 & 11.87 & 9.77 \\
20 & 20.10 & 20.47 & 28.37 & 14.33 & 81.70 & 41.30 \\
\hline Mean & 6.85 & 4.71 & 10.23 & 6.66 & 22.61 & 12.79 \\
\hline
\end{tabular}

dihasilkan masing-masing bahan bakar dengan timing injeksi yang sama memiliki tingkat yang berbeda. Opasitas gas buang yang menggunakan Pertamina Dex terlihat lebih rendah daripada yang menggunakan biosolar, baik pada timing standar, timing maju, maupun timing mundur. Hampir pada setiap pembebanan, dari beban rendah sampai beban tinggi, opasitas gas buang motor yang menggunakan Pertamina Dex lebih rendah daripada biosolar. Dengan demikian,dampak kepekatan gas buang motor diesel yang menggunakan bahan bakar Pertamina Dex lebih baik daripada yang menggunaan biosolar.

Berdasarkan data pengujian opasitas gas buang, jika dilihat dari timing injeksi yang divariasikan, terjadi perubahan nilai opasitas gas buang, baik untuk bahan bakar biosolar maupun Pertamina Dex saat tanpa beban, beban rendah sampai tinggi. Semakin besar pembebanan, nilai opasitasnya cenderung naik, dan nilainya melonjak ketika beban berat. Bila ditinjau dari timing injeksinya, nilai opasitas gas buang yang dihasilkan mesin pada timing maju lebih rendah daripada timing standar maupun timing yang dimundurkan.

\section{Pembahasan}

Terjadinya pembakaran pada motor diesel memanfaatkan temperatur udara yang tinggi dari hasil kompresi di ruang bakar. Oleh karena itu, pembakaran pada motor diesel terdiri atas beberapa tahap yaitu tahap penundaan pembakaran, perambatan pembakaran, pembakaran langsung, dan pembakaran lanjut. Pembakaran yang terjadi harus pada posisi yang tepat sesuai posisi torak, sehingga menghasilkan pembakaran yang optimal. Panjang pendeknya periode pembakaran tersebut secara langsung mempengaruhi proses pembakaran sehingga titik terjadinya pembakaran langsung pada posisi sudut engkol yang tepat dapat terjadi. Namun, periode proses pembakaran itu sendiri dipengaruhi berbagai hal, meliputi temperatur udara yang dikompresikan, waktu penginjeksian, sampai kualitas bahan bakar motor diesel.

Untuk mendapatkan pembakaran yang optimal, injeksi bahan bakar harus pada 
waktu yang tepat. Selain itu, properties bahan bakar juga mempengaruhi cepat lambatnya terjadinya pembakaran pada motor diesel. Spesifikasi bahan bakar yang sangat mempengaruhi hal ini adalah angka cetane (cetane number). Semakin tinggi nilainya, maka pembakaran yang terjadi lebih singkat sehingga lebih menguntungkan untuk kinerja motor.

Pertamina Dex dan biosolar memiliki angka cetane yang berbeda. Pertamina Dex memiliki angka cetane 51, sedangkan biosolar memiliki nilai angka cetane sebesar 48. Seperti yang diketahui secara teoritis, dengan angka cetane yang lebih tinggi maka menghasilkan dampak pembakaran yang lebih baik. Selain properties yang dimiliki masing-masing bahan bakar yang berhubungan dengan kecepatan pembakaran, timing injeksi secara teoritis akan berdampak pada mulainya pembakaran. Sebab dengan timing injeksi yang berbeda, titik mulainya penundaan pembakaran berada pada posisi torak yang berbeda, sehingga temperatur yang terjadi pada udara bertekanan di ruang bakar juga akan berbeda. Efeknya, pembakaran yang dihasilkan berbeda sehingga konsumsi bahan bakar akan berbeda pula, serta opasitas gas buang yang dihasilkan akan berpengaruh pula.

\section{Konsumsi Bahan Bakar pada Motor Diesel}

Sebagai motor bakar, konsumsi bahan bakar motor diesel merupakan hal yang diusahakan sehemat mungkin. Semakin besar energi yang mampu dibangkitkan mesin pada volume bahan bakar tertentu berarti performansi motor semakin baik.

Berdasarkan data penelitian pada dua jenis bahan bakar motor diesel yang populer di Indonesia, yaitu biosolar dan Pertamina Dex terdapat perbedaan nilai pembangkitan energi pada volume bahan bakar sama. Kondisi ini berlaku pada kondisi beberapa variasi timing injeksi yaitu timing injeksi standar, maju, maupun timing injeksi yang dimundurkan. Pembangkitan energi oleh motor diesel dengan bahan bakar yang berbeda pada timing standar, maju, dan mundur dengan berbagai pembebanan mesin, dapat dilihat pada Gambar 2, Gambar 3, dan Gambar 4.

Berdasarkan grafik yang ditunjukkan pada Gambar 2, 3, dan 4, dapat diketahui bahwa pada timing injeksi standar $\left(20^{\circ}\right.$ sebelum TMA) yang direkomendasikan pabrik, konsumsi bahan bakar motor diesel jika menggunakan pertamina dex cenderung lebih rendah dibanding dengan biosolar. Aplikasi bahan bakar Pertamina Dex lebih tinggi dibandingkan dengan

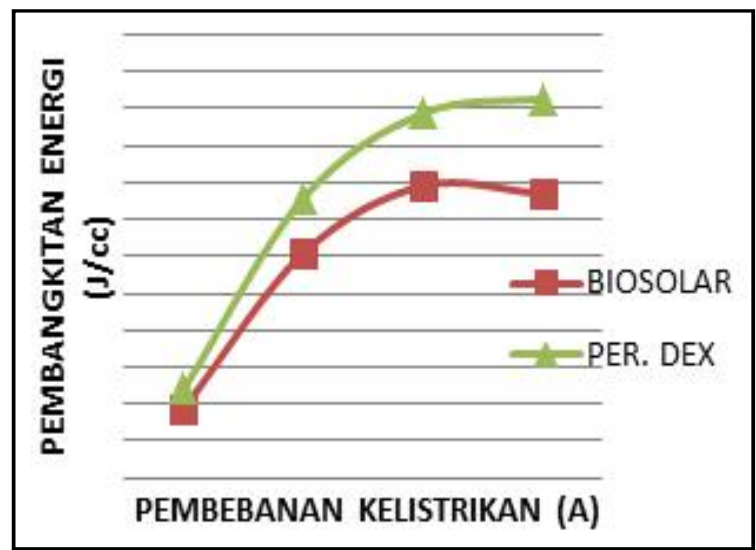

Gambar 2. Pencapaian Energi pada Timing Injeksi Standar 


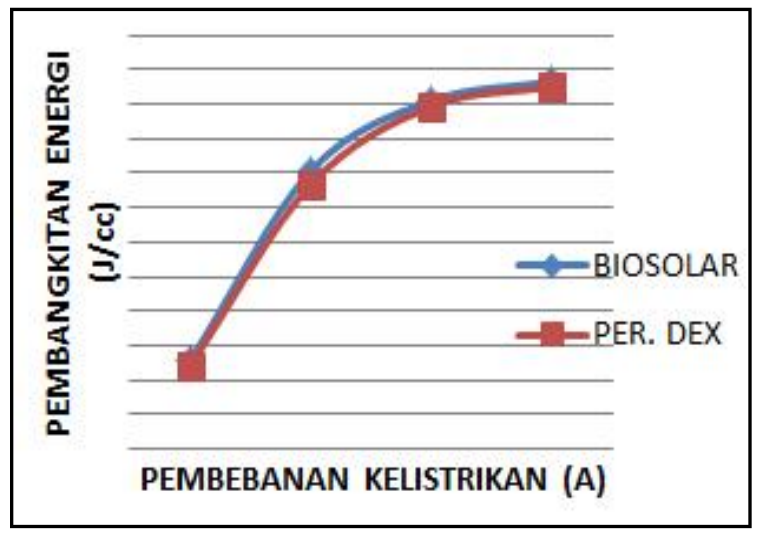

Gambar 3. Pencapaian Energi pada Timing Injeksi Maju

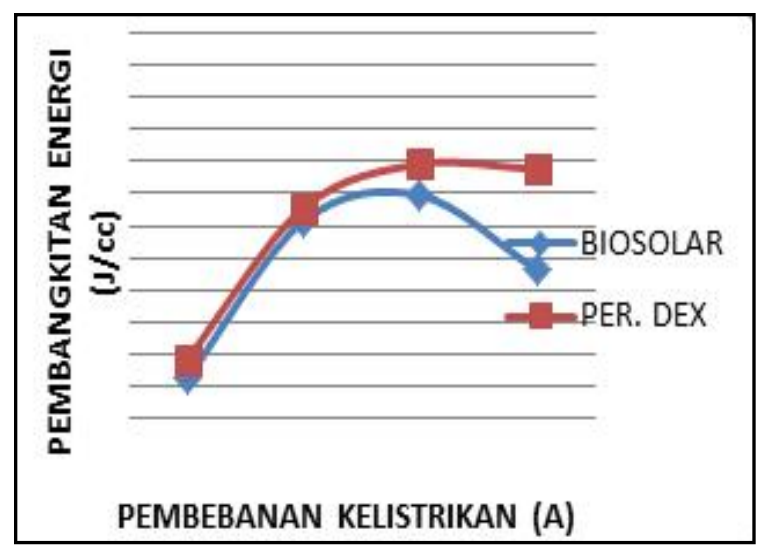

Gambar 4. Pencapaian Energi pada Timing Injeksi Mundur

penggunaan bahan bakar biosolar baik pada kondisi mesin tanpa beban, beban rendah, menengah maupun tinggi. Pada kondisi beban kelistrikan 15 ampere dengan tegangan 220V, atau setara dengan 3300 watt, pembangkitan energi dengan bahan bakar Pertamina Dex cenderung stabil pada kisaran 9000 joule/cc, sedangkan untuk biosolar energinya cenderung menurun dari 8000 joule/cc. Ketika timing penginjeksian dimajukan, terjadi perubahan besarnya pembangkitan energi oleh motor diesel pada masing-masing aplikasi bahan bakar.
Grafik pada Gambar 3 menunjukkan bahwa hasil pembangkitan energi antara kedua bahan bakar saat timing injeksi dimajukan hampir sama pada setiap kondisi beban. Dengan demikian, dapat dikatakan bahwa ketika timing injeksi dimajukan, konsumsi bahan bakar motor diesel tidak jauh berbeda antara penggunaan bahan bakar biosolar atau Pertamina Dex. Namun, ketika timing injeksi dimundurkan, konsumsi bahan bakar yang menggunakan bahan bakar Pertamina Dex dan biosolar cenderung berbeda. Ketika beban mesin rendah sampai menengah, konsumsi bahan bakar hampir sama, namun ketika beban mesin tinggi, konsumsi bahan bakarmotor diesel yang menggunakan biosolar jauh lebih tinggi daripada penggunaan Pertamina Dex. Hal ini dapat dilihat pada Gambar 4 bahwa ketika timing injeksi dimundurkan pada beban 15 ampere dengan tegangan 220 volt atau setara dengan beban 3300 watt, energi yang dibangkitkan pada penggunaan biosolar hanya 7500 joule setiap cc bahan bakar, sedangkan Pertamina Dex mampu membangkitkan energi pada kisaran 8000 joule pada volume yang sama. Pada beban kelistrikan lebih berat yaitu 20 A dengan tegangan sekitar 220 volt atau setara dengan 4400 watt, energi dengan aplikasi biosolar hanya berkisar 6400 joule/cc nya, sedangkan Pertamina Dex juga turun menjadi di bawah 8000 joule/cc bahan bakar. Dengan demikian dapat dilihat bahwa konsumsi bahan bakar 
yang paling efisien berada pada titik di mana terjadi pembangkitan energi yang paling besar pada setiap volume bahan bakarnya.

Perubahan timing injeksi ternyata memberikan dampak pada performansi mesin diesel yang dilihat dari pembangkitan energi pada setiap volume bahan bakarnya pada masing-masing jenis bahan bakar. Kondisi timing yang dimajukan $10^{\circ}$ memberikan dampak yang menguntungkan. Namun, ketika timing injeksi dimundurkan, energi yang dibangkitkan dalam setiap cc nya jauh lebih rendah. Dengan kata lain, konsumsi bahan bakar akan meningkat. Energi yang dibangkitkan melalui aplikasi biosolar pada timing injeksi standar, maju, dan dimundurkan dapat dilihat pada Gambar 5.

Tidak jauh berbeda pada penggunaan biosolar sebagai bahan bakar motor diesel, perubahan timing injeksi juga mempengaruhi

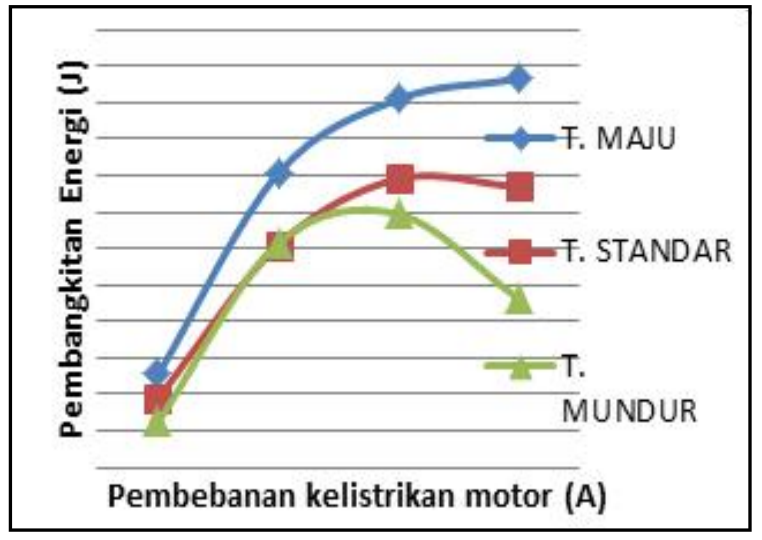

Gambar 5. Energi yang Dihasilkan dari Penggunaan Biosolar

energi yang dibangkitkan motor diesel pada aplikasi Pertamina Dex. Pada perubahan timing yang dilakukan, hasil energi pada setiap volume bahan bakarnya mengalami perubahan. Posisi timing injeksi standar memberikan kemampuan yang baik meskipun motor dibebani dengan beban tinggi. Saat timing injeksi sesuai standar puncak efisiensi performansi motor diesel berada pada pembebanan menengah saja (beban listrik 15 A), sedangkan ketika beban tinggi, konsumsi bahan bakarnya meningkat. Jika timing injeksi dimundurkan, performa motor diesel menurun ketika diberi pembebanan menengah sampai tinggi (beban kelistrikan 15-20 A pada voltase 220 Volt) konsumsi bahan. Hal ini dapat dilihat dari pembangkitan energinya yang turun cukup drastis pada titik ini. Hasil pembangkitan energi untuk Pertamina Dex pada berbagai timing injeksi motor diesel dapat dilihat pada Gambar 6 .

Sesuai dengan grafik pada Gambar 6, pada beberapa timing injeksi, performa motor diesel juga berbeda-beda pada penggunaan bahan bakar Pertamina Dex. Ketika timing injeksi standar atau dimajukan, motor diesel masih dapat bekerja dengan efisien meskipun

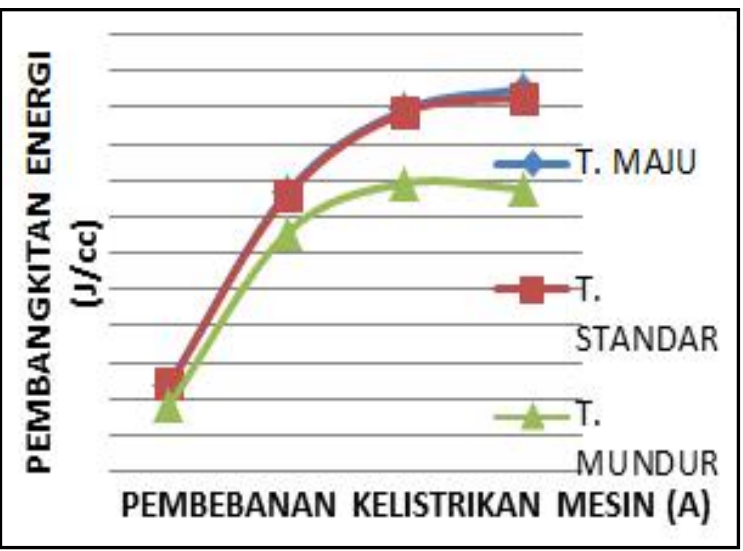

Gambar 6. Energi yang Dihasilkan dari Pertamina Dex 
pada beban menengah sampai tinggi (1520 ampere beban kelistrikan pada tegangan kerja 220 volt). Namun, ketika timing injeksi dimundurkan, pada pembebanan 15 ampere, efisiensi penggunaan bahan bakar cenderung turun. Hal ini dapat dilihat dari capaian energi yang dihasilkan setiap volume bahan bakarnya.

Berdasarkan data tersebut, timing injeksi memberikan pengaruh terhadap performa mesin diesel, baik pada penggunaan bahan bakar biosolar maupun Pertamina Dex. Selain hal tersebut, performa motor optimum yang dicapai terhadap pembebanan motor juga berbeda antara masing-masing bahan bakar. Pada kondisi timing standar dan dimundurkan, bahan bakar Pertamina Dex lebih unggul. Hal ini dapat terjadi karena spesifikasi angka cetane (cetane number) untuk Pertamina Dex lebih tinggi daripada biosolar. Angka cetane yang lebih tinggi memungkinkan terjadinya perambatan pembakaran lebih singkat yang dimulai dari periode penyalaan pembakaran yang lebih singkat. Hasilnya pembakaran yang terjadi pada motor diesel menjadi lebih baik. Tekanan pembakaran dapat terjadi sesuai dengan sudut engkol yang tepat. Berdasarkan teoritis, yaitu sekitar $10^{\circ}$ setelah TMA.

Dibanding dengan Pertamina Dex, biosolar memiliki angka cetane lebih rendah, yaitu 48. Hal ini berefek pada periode perambatan pembakaran yang lebih lama dibanding dengan Pertamina Dex. Pada posisi timing standar dan dimundurkan, waktu yang tersedia untuk terjadinya beberapa fase proses pembakaran lebih singkat, sebab posisi torak sudah lebih dekat dengan titik mati atas. Hal ini kurang menguntungkan bagi penggunaan biosolar, sebab tidak memiliki waktu yang cukup untuk menyelesaikan pembakaran dengan tepat. Selain itu, dengan timing yang mundur, kondisi temperatur udara di ruang bakar cenderung lebih tinggi sehingga berdampak pada pemanasan bahan bakar saat periode penundaan pembakaran. Dampaknya, dengan rambat pembakaran yang lebih lambat dengan temperatur udara yang lebih tinggi meskipun pemanasan bahan bakar cepat, namun perambatan pembakarannya terlambat, sehingga saat periode pembakaran langsung tidak berada pada waktu yang tepat, serta dapat mengakibatkan diesel knocking karena ketidakoptimalan pembakaran. Tekanan pembakaran maksimum tidak sesuai sudut engkol yang tepat, sehingga tekanan yang dihasilkan tidak termanfaatkan secara optimal.

Saat posisi timing injeksi dimajukan beberapa derajat, hasil pembakaran yang dihasilkan pada aplikasi biosolar meningkat, sedangkan untuk Pertamina Dex cenderung sama. Hal ini dapat terjadi karena pada posisi ini, cukup waktu bagi bahan bakar biosolar untuk terjadinya periode penundaan pembakaran dengan baik. Seperti yang diketahui sebelumnya, periode ini merupakan kondisi di mana bahan bakar disiapkan untuk terbakar. Dengan nilai angka cetane lebih rendah yang berakibat pada pembakaran yang lebih lama, dengan 
timing injeksi maju terjadinya perambatan dan pembakaran langsung tidak terlambat. Dampaknya, tekanan pembakaran yang dihasilkan sesuai dengan sudut engkol yang diinginkan. Hal ini sesuai grafik 5, pada timing maju, energi yang dibangkitkan setiap volume biosolar jauh lebih tinggi dibanding dengan saat timing injeksi standar maupun dimundurkan.

\section{Opasitas Gas Buang pada Motor Diesel}

Opasitas gas buang pada motor diesel terjadi karena terdapat partikulat-partikulat sisa pembakaran bahan bakar yang terbentuk dari dampak pembakaran motor diesel yang tidak sempurna. Berdasarkan data pengujian pada penggunaan biosolar dan Pertamina Dex dengan berbagai timing injeksi bahan bakar, terdapat nilai opasitas gas buang yang bervariasi. Nilai opasitas gas buang (dalam $\%$ ) pada masing-masing timing injeksi baik untuk aplikasi biosolar maupun Pertamina Dex dapat dilihat pada Gambar 7, 8, dan 9.

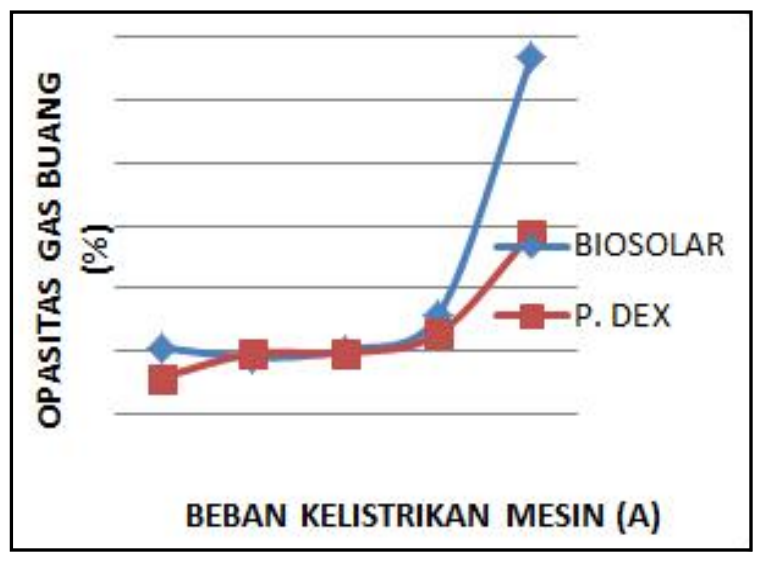

Gambar 7. Opasitas Gas Buang saat Timing Injeksi Standar

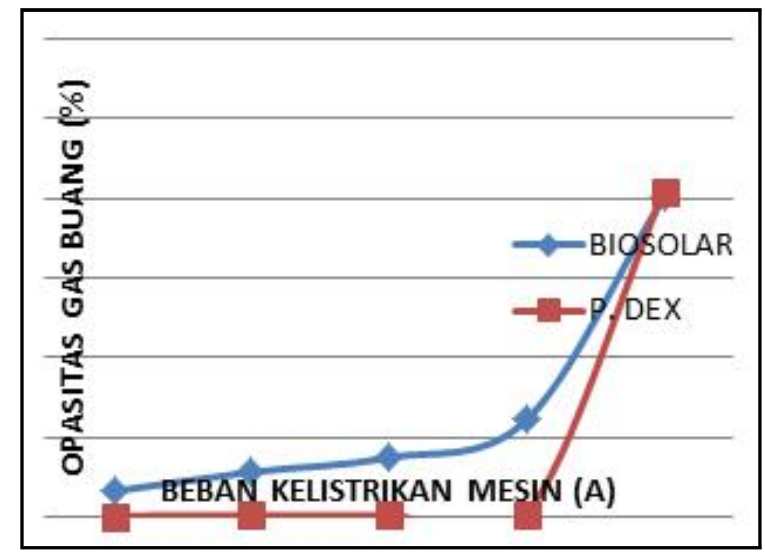

Gambar 8. Opasitas Gas Buang saat Timing Injeksi Maju

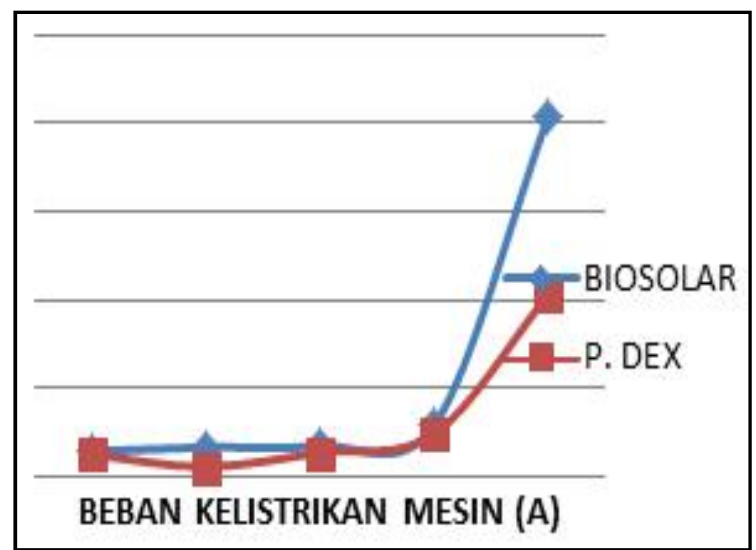

Gambar 9. Opasitas Gas Buang saat Timing Injeksi Mundur

Berdasarkan grafik pada Gambar 7, 8, dan 9, pada masing-masing timing injeksi menghasilkan opasitas gas buang yang berbeda antara penggunaan biosolar dengan Pertamina Dex. Saat timing standar, terlihat bahwa pada kondisi tanpa beban maupun beban tinggi, opasitas gas buang yang dihasilkan Pertamina Dex cenderung lebih rendah daripada pemakaian biosolar. Namun, pada kondisi beban menengah tidak terdapat perbedaan yang mencolok pada opasitas gas buang masing-masing penggunaan bahan 
bakar. Pada kondisi timing injeksi yang dimajukan $10^{\circ}$, opasitas gas buang yang dihasilkan Pertamina Dex jauh lebih rendah daripada yang dihasilkan pada pemakaian bahan bakar biosolar. Namun, pada kondisi beban berat, keduanya memberikan kenaikan opasitas yang cukup signifikan.

Saat timing injeksi dimundurkan $5^{\circ}$, masing-masing bahan bakar memberikan perbedaan nilai opasitas gas buangnya. Tidak jauh berbeda dengan kondisi timing standar, opasitas gas buang yang dihasilkan motor diesel dengan timing mundur cenderung hampir sama antara biosolar dan Pertamina Dex, sedangkan kenaikan opasitas pada keduanya terjadi juga pada beban yang berat. Terjadinya perbedaan ini tidak lain karena adanya perbedaan properties masing-masing bahan bakar antara Pertamina Dex dan biosolar yang mempengaruhi pembakaran.

Bila ditinjau dari dampak perubahan timing injeksi motor diesel pada masingmasing bahan bakar, terdapat perbedaan tingkat opasitas gas buang kondisi masingmasing timing injeksinya. Grafik dampak perubahan timing injeksi bahan bakar terhadap opasitas gas buang pada masingmasing jenis bahan bakar dapat dilihat pada Gambar 10 dan 11.

Berdasarkan data pada Gambar 10 dan 11, opasitas gas buang yang dihasilkan pada gas buang motor diesel yang menggunakan baik Pertamina Dex maupun biosolar memiliki kondisi yang rendah pada timing yang

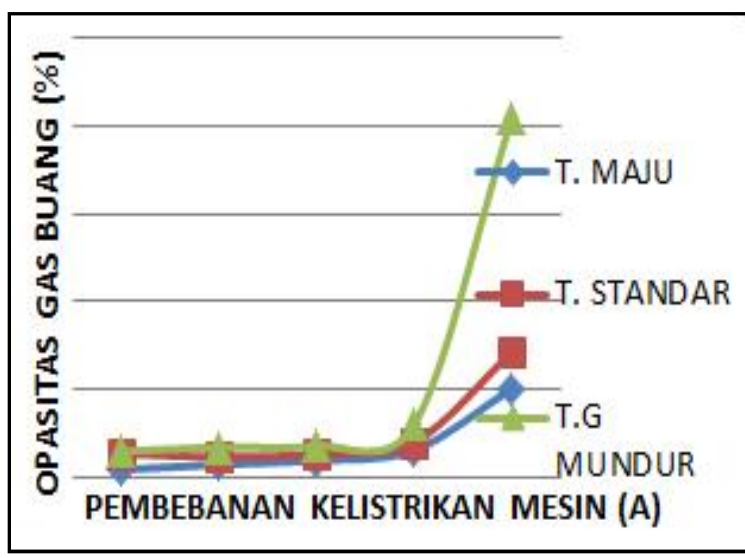

Gambar 10. Grafik Opasitas Gas Buang Motor Diesel pada Penggunaan Biosolar

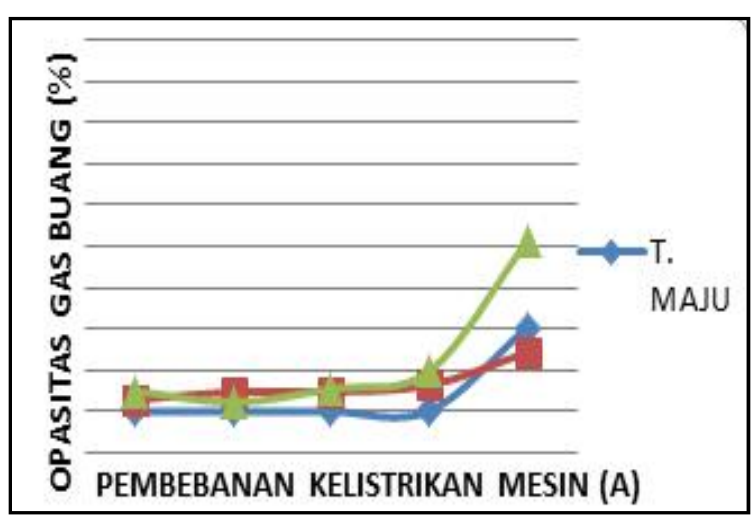

Gambar 11. Grafik Opasitas Gas Buang Motor Diesel pada Penggunaan Pertamina Dex

dimajukan dibanding dengan timing standar dan timing dimundurkan. Namun, jika ditinjau dari pembebanan yang diberikan, nilai opasitas gas buang meningkat cukup drastis ketika diberi beban tinggi (20 ampere beban kelistrikan dengan tegangan kerja 220 volt).

Opasitas gas buang merupakan bentuk kepekatan gas buang akibat partikulat sisa pembakaran motor diesel. Semakin baik pembakaran, maka opasitas gas buang juga semakin rendah. Opasitas gas buang juga dapat diakibatkan karena properties bahan 
bakar diesel yang kurang mendukung pada kondisi tertentu, seperti kandungan zat pengotornya. Saat timing injeksi dimajukan, opasitas gas buang cenderung lebih rendah. Hal ini dapat terjadi karena pada kondisi ini pembakaran yang terjadi pada masing-masing bahan bakar lebih baik. Dengan timing yang dimajukan pada obyek $10^{\circ}$ dari timing injeksi standar, bahan bakar memiliki sejumlah waktu yang cukup untuk terjadinya persiapan pembakaran seiring dengan perubahan posisi torak. Ketika fase berikutnya, bahan bakar dibakar pada fase perambatan pembakaran sampai pembakaran langsung. Dampaknya, pembakaran terjadi tanpa keterlambatan sehingga periode pembakaran lanjut dapat terjadi dengan waktu yang cukup. Efeknya, bahan bakar yang belum tuntas terbakar dapat terbakar pada periode ini.

Sebaliknya, ketika timing injeksi dimundurkan, opasitas gas buang yang terjadi cenderung meninggi baik untuk motor diesel yang menggunakan bahan bakar biosolar maupun Pertamina Dex. Hal ini dapat terjadi karena ketidaktuntasan pembakaran pada motor diesel. Ketidaktuntasan pembakaran dapat diakibatkan karena pembakaran yang terlambat. Ketika timing injeksi dimundurkan $5^{\mathrm{O}}$ dari timing injeksi standar, maka periode penundaan pembakaran menjadi mundur. Efeknya, periode perambatan pembakaran relatif lebih singkat. Efeknya, selain pembakaran langsung tidak tercapai dengan baik karena persiapan pembakaran pada semua partikel bahan bakar yang tidak sempurna, periode pembakaran lanjut menjadi tidak tuntas. Banyak bahan bakar yang belum terbakar. Akibatnya, muncul partikulat pada gas buang akibat ketidaktuntasan pembakaran bahan bakar.

Munculnya partikulat yang semakin tinggi juga terjadi sebagai akibat kenaikan beban mesin. Semakin tinggi beban mesin, maka bahan bakar yang diinjeksikan semakin banyak. Dampaknya, sisa bahan bakar yang tidak terbakar sempurna semakin banyak yang berakibat pada kepekatan gas buang yang tinggi. Selain itu, dengan pembebanan mesin yang terlalu tinggi, opasitas gas buang yang terjadi juga meningkat drastis. Ini terjadi karena injeksi bahan bakar pada posisi kuantitas maksimum.

Berdasarkan pembahasan terhadap data di atas, terdapat beberapa kondisi yang memungkinkan untuk mendapatkan performa motor diesel yang baik. Bila ditinjau dari konsumsi bahan bakar dan opasitas gas buang yang dihasilkan, pemajuan timing memberikan dampak yang baik ketika motor diesel diberikan beban-beban rendah dan menengah. Selain itu, untuk mendapatkan konsumsi bahan bakar yang rendah, rentang pembebanan mesin berada pada pembebanan menengah sampai pembebanan yang cukup tinggi, sehingga dihasilkan energi yang tinggi pada setiap volume bahan bakarnya yang berdampak pada rendahnya konsumsi bahan bakarnya. Namun, ketika diberikan 
Jurnal Penelitian Saintek, Vol. 20, Nomor 1, April 2015

pembebanan yang lebih tinggi, konsumsi bahan bakarnya cenderung naik, serta terjadi kenaikan opasitas gas buang yang drastis. Tentu saja hal ini merupakan hal yang kurang menguntungkan.

\section{KESIMPULAN}

Konsumsi bahan bakar motor diesel langkah yang paling efisien diperoleh ketika timing penginjeksian dimajukan sebesar $10^{\circ}$ dari timing standar ( $30^{\circ}$ sebelum TMA) baik pada pengaplikasian bahan bakar biosolar maupun Pertamina Dex. Kemudian diikuti dengan pengaplikasian timing standar dan konsumsi bahan bakar meningkat ketika timing penginjeksian bahan bakarnya dimundurkan sebesar $5^{\circ}$ dari timing standar. Opasitas gas buang motor diesel empat langkah berada pada kondisi yang paling baik atau opasitasnya paling rendah yaitu pada kondisi timing penginjeksian dimajukan sebesar $10^{\circ}$ dari timing standar $\left(30^{\circ}\right.$ sebelum TMA) baik pada pengaplikasian bahan bakar biosolar maupun Pertamina Dex.

\section{DAFTAR PUSTAKA}

Anonim. 2011. 70 Persen Pencemaran Udara karena Motor. Diambil dari http://www. antarajatim.com/lihat/berita/68873/70persen-pencemaran-udara-karenamotor pada 19 Maret 2014.

Anonim. 2014. Harga Resmi BBM dalam Kemasan. Diambil dari m.tempo.co pada 30 Juli 2014.
Departemen Energi dan Sumber Daya Mineral RI. (2006). Keputusan Direktur Jenderal Minyak dan gas Bumi Nomor 3675 K/24/DJM/2006, tentang Standar Baku Mutu (Spesifikasi) Bahan Bakar Minyak Jenis Minyak Solar yang Dipasarkan di Dalam Negeri.

Garrett, T.K., Newton, K., dan Steeds, W. 2001. The Motor Vehicle. Butterworth: Reed Educational and Professional Publishing Ltd.

Hermawan. 2004. Studi Eksperimental tentang Pengaruh Perubahan Timing Injeksi terhadap Unjuk Kerja Mesin Diesel Empat Langkah Berbahan Bakar Ganda. Undergraduated Thesis. Institut Teknologi Surabaya, Surabaya.

Heywood, J.B. 1988. Internal Combustion Engine Fundamentals. New York: McGraw Hill. Inc.

Rofiq, A. 2011. Analisis Perbandingan Performa dan Emisi Gas Buang Motor Diesel dengan Menggunakan Bahan Bakar Biosolar dan Pertamina Dex. Undergraduated Thesis. Institut Tekno-logi Surabaya, Surabaya.

Sukoco dan Arifin, Z. 2008. Teknologi Motor Diesel. Bandung: Alfabeta.

Sukoco dan Arifin, Z. 2009. Pengendalian Polusi Kendaraan. Bandung: Alfabeta.

Supriyatno, B. 2007. Analisis Perbandingan Unjuk Kerja Motor Diesel dengan Menggunakan Bahan Bakar Solar dan Solar Dex. Skripsi (tidak diterbitkan). Universitas Tarumanegara. Jakarta. 